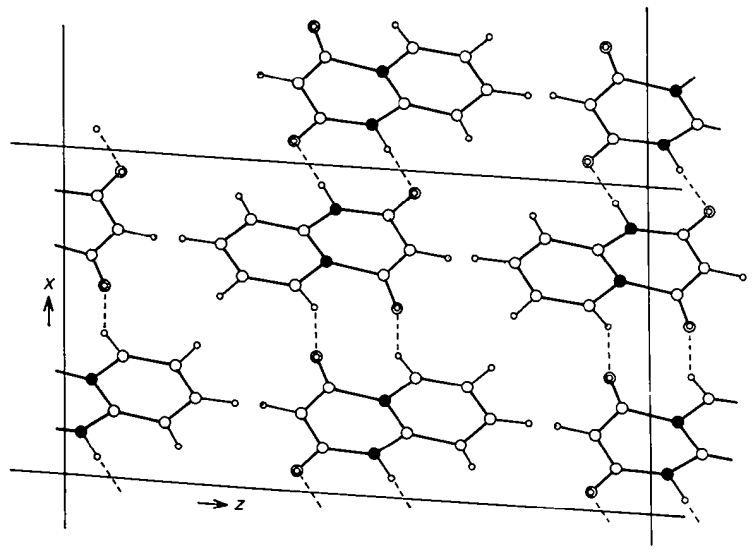

Fig. 3. Projection of the crystal structure down the $b$ axis. Black circles: $\mathrm{N}$ atoms, double circles: $\mathrm{O}$ atoms. The dotted lines represent the hydrogen-bonding system.

$1.345(2)$ and $\mathrm{N}(5)-\mathrm{C}(10) 1.355$ (2) $\AA$ (Fig. 2) have values characteristic of $\mathrm{C}-\mathrm{N}$ partial double bonds. International Tables for X-ray Crystallography (1962) gives $1.352(5) \AA$ for such bonds. There is a significant difference between the bonds $\mathrm{C}(2)-\mathrm{O}(2) 1.251$ (2) and $\mathrm{C}(4)-\mathrm{O}(4) 1.228$ (2) $\AA$; this may be because $\mathrm{O}(2)$ and $\mathrm{O}(4)$ are involved in a strong and a weak intermolecular hydrogen bond, respectively.

The crystal structure is stabilized by pairs of hydrogen bonds grouped around centres of symmetry (Fig. 3). Two types of hydrogen bonds occur: strong linear $\mathrm{N}(1)-\mathrm{H}(1) \ldots \mathrm{O}(2)$ bonds and weak bent $\mathrm{C}(6)-$ $\mathrm{H}(1) \cdots \mathrm{O}(4)$ bonds; the former agrees well with the observation that strong $\mathrm{N}-\mathrm{H} \cdots \mathrm{O}$ hydrogen bonds prefer a linear or nearly linear arrangement (Taylor, Kennard \& Versichel, 1984). The hydrogen-bond dimensions are: $\mathrm{N}(1)-\mathrm{H}(1) \quad 1.00(3), \quad \mathrm{H}(1) \cdots \mathrm{O}(2)$ $1.70(3), \mathrm{N}(1) \ldots \mathrm{O}(2) 2.698(2) \AA, \mathrm{N}(1)-\mathrm{H}(1) \ldots \mathrm{O}(2)$ $179(3)^{\circ}$; and $\mathrm{C}(6)-\mathrm{H}(6) \quad 0.97(3), \quad \mathrm{H}(6) \cdots \mathrm{O}(4)$ $2.33(3), \mathrm{C}(6) \cdots \mathrm{O}(4) 3 \cdot 180(2) \AA, \mathrm{C}(6)-\mathrm{H}(6) \cdots \mathrm{O}(4)$ $146(3)^{\circ}$.

Financial support from the Danish Natural Science Research Council and Thomas B. Thriges Foundation for the purchase of the $\mathrm{X}$-ray diffraction equipment is gratefully acknowledged.

\section{References}

Dvortsák, P., Resofszki, G., Huhn, M., Zalántai, L. \& Kiss, A. I. (1976). Tetrahedron, 32,2117-2120.

International Tables for X-ray Crystallography (1962). Vol. III. Birmingham: Kynoch Press. (Present distributor D. Reidel, Dordrecht.)

International Tables for X-ray' Crystallography (1974). Vol. IV, pp. 99, 149. Birmingham: Kynoch Press. (Present distributor D. Reidel, Dordrecht.)

Katritzky, A. R. \& Waring, A. J. (1962). J. Chem. Soc. pp. 1544-1548.

Main, P., Fiske, S. J., Hull, S. E., Lessinger, L., Germain, G., DeClercQ, J.-P. \& WoOlfson, M. M. (1980). MULTAN80. A Sy'stem of Computer Programs for the Automatic Solution of Crystal Structures from X-ray Diffraction Data. Univs. of York, England, and Louvain, Belgium.

SNyder, H. R. \& Robinson, M. M. (1952). J. Am. Chem. Soc. 74, 4910-4916.

Stewart, J. M., Machin, P. A., Dickinson, C. W., Ammon, H. L., HeCk, H. \& Flack, H. (1976). The XRA Y76 system. Tech. Rep. TR-446. Computer Science Center, Univ. of Maryland, College Park, Maryland, USA.

TAylor, R., KenNard, O. \& Versichel, W. (1984). Acta Cryst. B40, 280-288.

Tschitschibabin, A. E. (1924). Ber. Dtsch. Chem. Ges. 57, $1168-1172$.

Urban, R. Grosjean, F. \& Arnold, W. (1970). Helv. Chim. Acta, 53, 905-922.

Acta Cryst. (1985). C41, 474-476

\title{
3-Ethoxy-5,6,7,8-tetrahydro-1-hydroxyisoquinoline-4-carbonitrile, $\mathrm{C}_{12} \mathrm{H}_{14} \mathrm{~N}_{2} \mathrm{O}_{2}$
}

\author{
By S. SALISI AND J. L. BRIANSÓ
}

Departamento de Cristalografía y Mineralogía, Universidad Autónoma de Barcelona, Bellaterra (Barcelona), Spain

and X. Solans and M. Font-Altaba

Departamento de Cristalografía y Mineralogia, Universidad de Barcelona, Gran Via 585, Barcelona 08007. Spain

(Received 3 May 1984; accepted 17 July 1984)
Abstract. $M_{r}=218 \cdot 25$, monoclinic, $P 2_{1} / n, \quad a=$ $1.33 \mathrm{~g} \mathrm{~cm}^{-3}, \lambda(\mathrm{Mo} K \alpha)=0.71069 \AA, \quad \mu=0.86 \mathrm{~cm}^{-1}$, $20.000(2), \quad b=6.219(1), \quad c=8.794$ (1) $\AA, \quad \beta=$ $F(000)=464, T=298 \mathrm{~K}$. Final $R=0.056$ for 1369 $94.31(2)^{\circ}, \quad V=1090 \cdot 7(4) \AA^{3}, \quad Z=4, \quad D_{x}=$ observed reflections. The pyridine ring is planar; two 0108-2701/85/030474-03\$01.50 c c 1985 International Union of Crystallography 
(carbonyl and carbonitrile) substituents deviate at the same side of the plane, while the remaining substituents deviate at the other side. The six-carbon-membered ring has a skew-boat form. Bond angles and lengths are similar to those observed in the literature. Enantiomeric molecules are hydrogen-bonded by means of the carbonyl $\mathrm{O}$ and the $\mathrm{N}$ atom of the isoquinoline moiety.

Introduction. The Knoevenagel condensation between ethyl 2-oxocyclohexanecarboxylate and malononitrile in basic media (Sempere, 1983) affords a reaction product different from that obtained in acid media (Van der Baan \& Bickelhaupt, 1968, 1970; Kasturi \& Sharma, 1975). The molecular structure could not be completely determined by IR, NMR, UV and mass methods and an X-ray analysis was undertaken to elucidate the molecular structure and geometry of the compound.

Experimental. Yellow elongated prisms $(0.1 \times 0.1 \times$ $0.3 \mathrm{~mm}$ ). Philips PW-1100 diffractometer, Mo $K \alpha$, graphite monochromator, $\omega$-scan technique, cell parameters from 25 reflections $\left(4 \leq \theta \leq 12^{\circ}\right)$. 1395 independent reflections with $\theta \leq 25^{\circ}$, range of $h \mathrm{kl}=\overline{22}$ to 22,0 to 7,0 to $10 ; 1369$ with $I \geq 2 \cdot 5 \sigma(I)$. No significant variation in intensity of three standard reflections, absorption ignored. Non-H atoms from MULTAN80 (Main, Fiske, Hull, Lessinger, Germain, Declercq \& Woolfson, 1980). Isotropic and anisotropic full-matrix least-squares refinement with SHELX76 (Sheldrick, 1976), H from $\Delta F$ synthesis, refined with an overall isotropic temperature factor. Function minimized $\quad w|| F_{o}|-| F_{c}||^{2}, \quad w=\left[\sigma^{2}\left(F_{o}\right)+\right.$ $\left.0.0146\left|F_{o}\right|^{2}\right]^{-1} ; \quad$ final $R=0.056, \quad R_{w}=0.072$, $(\Delta / \sigma)_{\max }=1.9\left[\right.$ in $U_{33}$ of $\left.\mathrm{O}(11)\right] . \Delta \rho$ excursions $=0.3$ $[1.24 \AA$ from $\mathrm{C}(5)]$ and $-0.3 \mathrm{e} \AA^{-3} \cdot f_{f}^{\prime}$ and $f^{\prime \prime}$ from International Tables for X-ray Crystallography (1974). IBM 4341 computer.

Discussion. Final atomic parameters are given in Table $1,{ }^{*}$ bond distances and angles in Table 2. Fig. 1 shows a perspective view of the molecule.

The determination of the crystal structure shows the positions of the substituents. The pyridine ring is planar, with largest deviations from atoms to mean plane -0.010 (4) $\AA$ in $C(1)$ and 0.010 (4) $\AA$ in $C(2)$. O(16) and the carbonitrile group deviate to the same side of the plane $[O(16) 0.018$ (3) and $C(14) 0.038$ (4) $\AA]$, while the ethoxy group and the six-carbon ring deviate to the other side $[\mathrm{O}(11)-0.038(3), \mathrm{C}(7)-0.033$ (4) and $\mathrm{C}(4)-0.033$ (4) $\AA$ J. The six-carbon ring has

\footnotetext{
* Lists of structure factors, anisotropic thermal parameters and $\mathrm{H}$-atom coordinates have been deposited with the British Library Lending Division as Supplementary Publication No. SUP 39622 (9 pp.). Copies may be obtained through The Executive Secretary International Union of Crystallography, 5 Abbey Square, Chester CH1 2HU, England.
}

a skew-boat conformation. Enantiomeric molecules are hydrogen-bonded $\left\{\mathrm{N}(10)-\mathrm{H}(\mathrm{N} 10) \ldots \mathrm{O}\left(16^{i}\right)\right.$; $d\left[\mathrm{~N}(10) \cdots \mathrm{O}\left(16^{\mathrm{i}}\right)\right]=2.821(3), \quad d\left[\mathrm{H}(\mathrm{N} 10) \cdots \mathrm{O}\left(16^{\mathrm{i}}\right)\right]=$ 1.98 (3) $\AA$, (i) $=2-x, y, 1-z\}$.

This work was sponsored by the University of Barcelona.

Table 1. Atomic coordinates $\left(\times 10^{4}\right)$ and equivalent isotropic temperature coefficients

\begin{tabular}{rcrc}
\multicolumn{4}{c}{$B_{\mathrm{eq}}=\frac{8}{3} \pi^{2} \sum_{i} \sum_{j} U_{i j} a_{i}^{*} a_{j}^{*} \mathbf{a}_{i} \cdot \mathbf{a}_{j}}$. \\
$x$ & $y$ & $z$ & $B_{\mathrm{eq}}\left(\AA^{2}\right)$ \\
$9429(2)$ & $4278(7)$ & $3231(5)$ & $2 \cdot 9(2)$ \\
$9756(2)$ & $5778(7)$ & $2421(5)$ & $2 \cdot 8(2)$ \\
$10452(2)$ & $5481(7)$ & $2198(5)$ & $2 \cdot 7(2)$ \\
$10789(3)$ & $7140(9)$ & $1248(7)$ & $3 \cdot 9(3)$ \\
$11480(3)$ & $6340(12)$ & $777(9)$ & $5 \cdot 8(3)$ \\
$11879(3)$ & $5213(10)$ & $1984(9)$ & $5 \cdot 5(3)$ \\
$11525(2)$ & $3318(8)$ & $2617(8)$ & $3 \cdot 9(2)$ \\
$10793(2)$ & $3762(7)$ & $2818(5)$ & $2 \cdot 8(2)$ \\
$10452(2)$ & $2215(7)$ & $3681(5)$ & $2 \cdot 8(2)$ \\
$9771(2)$ & $2587(6)$ & $3848(4)$ & $2 \cdot 8(2)$ \\
$8775(1)$ & $4529(5)$ & $3394(4)$ & $3 \cdot 6(2)$ \\
$8379(2)$ & $2747(9)$ & $3893(8)$ & $4 \cdot 0(2)$ \\
$7661(3)$ & $3453(11)$ & $3695(9)$ & $5 \cdot 1(3)$ \\
$9385(2)$ & $7600(8)$ & $1816(6)$ & $3 \cdot 4(2)$ \\
$9090(2)$ & $9052(7)$ & $1331(6)$ & $4 \cdot 6(2)$ \\
$10723(2)$ & $614(5)$ & $4298(4)$ & $3 \cdot 8(2)$
\end{tabular}

Table 2. Bond distances $(\AA)$ and angles $\left(^{\circ}\right)$

$\begin{array}{llll}\mathrm{C}(1)-\mathrm{C}(2) & 1.378(4) & \mathrm{C}(6)-\mathrm{C}(7) & 1.507(4) \\ \mathrm{C}(1)-\mathrm{N}(10) & 1.350(3) & \mathrm{C}(7)-\mathrm{C}(8) & 1.514(4) \\ \mathrm{C}(1)-\mathrm{O}(11) & 1.336(3) & \mathrm{C}(8)-\mathrm{C}(9) & 1.439(4) \\ \mathrm{C}(2)-\mathrm{C}(3) & 1.433(4) & \mathrm{C}(9)-\mathrm{N}(10) & 1.400(3) \\ \mathrm{C}(2)-\mathrm{C}(14) & 1.439(4) & \mathrm{C}(9)-\mathrm{O}(16) & 1.243(3) \\ \mathrm{C}(3)-\mathrm{C}(4) & 1.527(4) & \mathrm{O}(11)-\mathrm{C}(12) & 1.452(3) \\ \mathrm{C}(3)-\mathrm{C}(8) & 1.365(3) & \mathrm{C}(12)-\mathrm{C}(13) & 1.500(4) \\ \mathrm{C}(4)-\mathrm{C}(5) & 1.557(4) & \mathrm{C}(14)-\mathrm{N}(15) & 1.146(3) \\ \mathrm{C}(5)-\mathrm{C}(6) & 1.474(5) & & \\ \mathrm{N}(10)-\mathrm{C}(1)-\mathrm{C}(2) & 119.8(2) & \mathrm{C}(8)-\mathrm{C}(7)-\mathrm{C}(6) & 112.8(2) \\ \mathrm{O}(11)-\mathrm{C}(1)-\mathrm{C}(2) & 119.1(2) & \mathrm{C}(7)-\mathrm{C}(8)-\mathrm{C}(3) & 123.5(2) \\ \mathrm{O}(11)-\mathrm{C}(1)-\mathrm{N}(10) & 121.1(2) & \mathrm{C}(9)-\mathrm{C}(8)-\mathrm{C}(3) & 120.1(2) \\ \mathrm{C}(3)-\mathrm{C}(2)-\mathrm{C}(1) & 119.4(2) & \mathrm{C}(9)-\mathrm{C}(8)-\mathrm{C}(7) & 116.4(2) \\ \mathrm{C}(14)-\mathrm{C}(2)-\mathrm{C}(1) & 118.7(2) & \mathrm{N}(10)-\mathrm{C}(9)-\mathrm{C}(8) & 116.8(2) \\ \mathrm{C}(14)-\mathrm{C}(2)-\mathrm{C}(3) & 121.9(2) & \mathrm{O}(16)-\mathrm{C}(9)-\mathrm{C}(8) & 124.5(2) \\ \mathrm{C}(4)-\mathrm{C}(3)-\mathrm{C}(2) & 117.7(2) & \mathrm{O}(16)-\mathrm{C}(9)-\mathrm{N}(10) & 118.7(2) \\ \mathrm{C}(8)-\mathrm{C}(3)-\mathrm{C}(2) & 120.3(2) & \mathrm{C}(9)-\mathrm{N}(10)-\mathrm{C}(1) & 123.5(2) \\ \mathrm{C}(8)-\mathrm{C}(3)-\mathrm{C}(4) & 121.9(2) & \mathrm{C}(12)-\mathrm{O}(11)-\mathrm{C}(1) & 120.4(2) \\ \mathrm{C}(5)-\mathrm{C}(4)-\mathrm{C}(3) & 120.0(3) & \mathrm{C}(13)-\mathrm{C}(12)-\mathrm{O}(11) & 106.3(3) \\ \mathrm{C}(6)-\mathrm{C}(5)-\mathrm{C}(4) & 113.2(3) & \mathrm{N}(15)-\mathrm{C}(14)-\mathrm{C}(2) & 179.8(1) \\ \mathrm{C}(7)-\mathrm{C}(6)-\mathrm{C}(5) & 114.0(3) & & \end{array}$

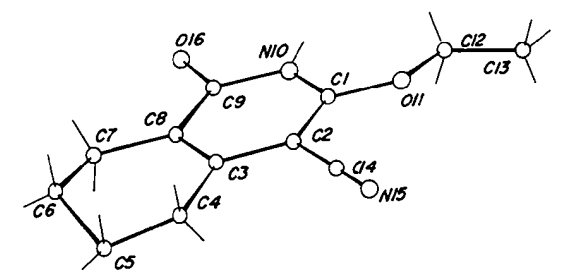

Fig. 1. View of the molecule, with the arbitrary numbering of the atoms. 


\section{References}

International Tables for X-ray Crystallography (1974). Vol. IV, pp. 100 , 150. Birmingham: Kynoch Press.

KASTURI, T. R. \& Sharma, V. K. (1975). Tetrahedron, 31, 527-531.

Main, P., Fiske, S. J., Hull, S. E., Lessinger, L., Germain, G., DEClERCQ, J.-P. \& WOOLFSON, M. M. (1980). MULTAN80. A System of Computer Programs for the Automatic Solution of Crystal Structures from X-ray Diffraction Data. Univs. of York, England, and Louvain, Belgium.
Sempere, J. (1983). New Synthesis of Pyridol3,4-d]pyridazines. PhD Thesis, IQS., Barcelona, Spain.

Sheldrick, G. M. (1976). SHELX76. Program for crystal structure determination. Univ. of Cambridge, England.

Van der BaAn, J. L. \& Bickelhaupt, F. (1968). Chem. Commun. pp. 1661-1662.

Van der BaAn, J. L. \& Bickelhaupt, F. (1970). Chem. Commun. pp. 326-327.

Acta Cryst. (1985). C41, 476-479

\title{
sym-Triphenylcyclopropenylium Hexabromotellurate(IV), $\left(\mathrm{C}_{21} \mathrm{H}_{15}\right)_{2}\left[\mathrm{TeBr}_{6}\right]$
}

\author{
By Brandan A. Borgias, Robert C. Scarrow, Mark D. Seidler and Wayne P. Weiner \\ Department of Chemistry, University of California, Berkeley, California 94720, USA
}

(Received 19 June 1984; accepted 24 October 1984)

\begin{abstract}
M_{r}=1141 \cdot 7$, monoclinic, $P 22_{1} / c, \quad a=$ $13.663(1), \quad b=13.360(1), \quad c=21.718(2) \AA, \quad \beta=$ $93.612(7)^{\circ}, \quad V=3956(1) \AA^{3}, \quad Z=4, \quad D_{m}=1.92$, $D_{x}=1.912 \mathrm{~g} \mathrm{~cm}^{-3}, \quad \lambda($ Mo $K \alpha)=0.71073 \AA$ A,$\quad \mu=$ $67.85 \mathrm{~cm}^{-1}, F(000)=2176$, room temperature, final $R=0.026$ for 3500 independent observed reflections. The $\mathrm{TeBr}_{6}^{2-}$ anion is nearly octahedral with the $\mathrm{Te}-\mathrm{Br}$ bonds ranging from 2.69 to $2.72 \AA$ and the $\mathrm{Br}-\mathrm{Te}-\mathrm{Br}$ angles ranging from 87.6 to $92 \cdot 1^{\circ}$. The average cyclopropenylium $\mathrm{C}-\mathrm{C}$ bond distance is $1.377 \AA$. The planes of the phenyl rings are twisted relative to the plane of the cyclopropenylium ring by $c a 5^{\circ}$.
\end{abstract}

Introduction. The geometry of the hexahalotellurate dianion $\left(\mathrm{Te} X_{6}^{2-}\right)$ has provoked considerable interest (Clark, McWhinnie, Mallaki, Dance \& Jones, 1980). A distorted octahedral configuration is predicted by valence shell electron pair repulsion (VSEPR) theory (Gillespie \& Nyholm, 1957). However, work based on MO theory predicts regular octahedral geometry (Gillespie, 1970; Johnstone, Jones \& Vasudev, 1972). Several 'undistorted' structures of the $\mathrm{TeBr}_{6}^{2-}$ anion have been reported (Brown, 1964; Das \& Brown, 1966; Dahan \& Lefebvre-Soubeyran, 1976a; Berg \& Nielsen, 1979); however, only in the most recent study were the data corrected for absorption. In each case the dianion possesses crystallographically imposed point symmetry: $\overline{1}, m 3 m, 2, \overline{3}$ respectively. Another structure (Dahan \& Lefebvre-Soubeyran, 1976b) also locates the $\mathrm{TeBr}_{6}^{2-}$ at a position with twofold symmetry; the dianion is slightly distorted possibly due to hydrogen bonding involving the $\mathrm{Br}$ atoms $[\mathrm{Te}-\mathrm{Br}$ distances range from 2.642 (3) to 2.798 (3) $\AA$; $\mathrm{Br}-\mathrm{Te}-\mathrm{Br}$ angles range from 85.7 (1) to $93.0(1)^{\circ}$ ]. Several $\mathrm{Te} X_{6}^{2-}(X=\mathrm{Cl}$ or

0108-2701/85/030476-04\$01.50
I) structures have been reported but only one shows a clearly distorted $\mathrm{TeCl}_{6}^{2-}$ anion (Russo, Valle \& Calogero, 1980). This is also hydrogen-bonded to the cation.

The structure of the sym-triphenylcyclopropenylium cation (TPCP) has been reported by Sundaralingam \& Jensen (1966). The short cyclopropenylium C-C distance observed in that structure $[1.373(5) \AA]$ is in excellent agreement with the distance predicted for the $\mathrm{C}_{3} \mathrm{H}_{3}^{+}$structure $(1.377 \AA$ ) (Radom, Hariharan, Pople $\&$ Schleyer, 1976). However, the apparent distortion of the phenyl rings $(\mathrm{C}-\mathrm{C}$ distances range from 1.338 to $1.444 \AA$ in a single phenyl ring) is disturbing.

In this paper we report the structure of $(\mathrm{TPCP})_{2}\left[\mathrm{TeBr}_{6}\right]$. By collecting a relatively high-angle data set, and by accounting for absorption effects, we hoped to generate superior structures for both the TPCP cation and the $\mathrm{TeBr}_{6}^{2-}$ anion.

Experimental. Diffraction-quality crystals supplied by Mr Kenneth A. Smith of the Department of Chemistry, University of California, Berkeley. Crystal density measured by flotation in toluene/bromoform. Orange crystals, elongated parallelepipeds $(0.25 \times 0.21 \times$ $0.18 \mathrm{~mm}$ ) with bevelled corners.

Enraf-Nonius CAD-4 diffractometer. Cell dimensions determined using 24 well centered reflections with $28<2 \theta<40^{\circ}$. All reflections with $0.037<\sin \theta / \lambda<$ $0.583 \AA^{-1} \quad(0 \leq h \leq 15, \quad 0 \leq k \leq 15, \quad-25 \leq l \leq 25)$ measured using $\omega-2 \theta$ scans with following conditions: aperture, vertical $3.0 \mathrm{~mm}$, horizontal $(0.55+$ $0.35 \tan \theta) \mathrm{mm}$; scan width, $(2.0+1.0 \tan \theta)^{\circ}$; background, $25 \%$ each side of peak scan; pre-scan rate $6.7^{\circ} \mathrm{min}^{-1}$; additional scan if $0.015<\sigma(I) /(I)<1$,

(c) 1985 International Union of Crystallography 